\title{
Information Technology Capability for Nigerian Public Tertiary Institutions: A Tool for Gaining Competitive Advantage
}

\author{
Ahmad Aliyu Palladan ${ }^{a^{*},}$ Kadzrina Abdul Kadir ${ }^{b}$ \\ aSchool of Business Education, Federal College of Education (Tech), Ashaka Road Gombe, Nigeria \\ ${ }^{b}$ College of Business, Universiti Utara Malaysia, Sintok, Kedah, Malaysia \\ *Corresponding author: ahmed_palladan@oyasgb.uum.edu.my
}

\begin{abstract}
The essence of this conceptual paper is to broaden the notion of IT capability, which hitherto was more pronounced in the banking, communication and other for profit organizations. Information Technology Capability (IT Capability) refers to institution's ability to manipulate and exploit opportunities avails by ICT to create something more new and more superb for the betterment of the institution and to attain competitive advantages. Some benefits attached to IT capability include rapid and quick processing of transactions, error minimization, cost saving as well as improvement of productivity. The paper suggest more investment on IT objects, IT operation and IT knowledge as sub dimensions of IT capability. Thus, this will go a long way in enhancing the competitive advantage of public tertiary institutions in Nigeria.
\end{abstract}

Keywords: Information technology capability, tertiary institutions, competitive advantage, Nigeria

(C) 2016 Penerbit UTM Press. All rights reserved

\subsection{INTRODUCTION}

The dramatical changes taking place in the higher education sector globally is compelling educational managers to switch from conventional style of management the institutions to more creative and dynamic practices. This is due to the high level of competition taking place in the sector and persistence demand of increase for quality from different stakeholders as well as decline in government funding. This trend is pushing many higher education institutions to start adopting all the necessary measures that will enhance their performance and ensure students and stakeholder's satisfaction. Kong (2010) posited that public tertiary institutions are operating in a competitive environment characterized by continuous demand of service quality from community, increasing fierce competition from private sector, declining volunteer support as well as shrinking government funding.

Tertiary institutions are focusing on ways to render superb and high quality services to their clients as well as struggling to attain better competitive advantage (Farid, Nejati \& Mirta, 2008). As a result, the focus of tertiary institutions is no longer to graduate students only, but also improve organizational performance in all dimensions. The issue of higher educational efficiency is continued to gain more and more attention world over (Kazee, 2010). Gusau (2008) pointed out that several commissions of inquiry were established and many conferences were held in order to discuss issues regarding the performance of public tertiary institutions in Nigeria.

To enhance the efficiency of tertiary through performance, the role of IT could not be over emphasized. Oyedijo, (2012) argued that the impact of information technology is recently manifesting challenge upon the tertiary institutions. Information technology that penetrates institutional activities helps in shortening the period of responding to change and information processing. Tertiary institutions that fail to exploit IT properly, argued Macharia and Nyakwende (2014), risk losing to other organization that do. This emerging trend is particularly true to tertiary in Nigeria, a nation situated in sub Saharan Africa, a region where the usage and access to IT is in the rapid increase (Ajazeera, 2016). Also, Adegbji and Akporhonor (2005) concurred that students in tertiary institutions are increasingly seeking for more advance and sophisticated method of information acquisition, application and manipulation and are showing more and more preference to universities and colleges with greater and more advanced IT based resources.

Information Technology (IT) is a force that has altered many aspects of human's ways of life. Bearing in mind areas like medicine, tourism, transport, business, banking, to mentioned a few. The impact of IT in the past two to three decades has been pervasive (Adeoye, Oluwole, \& Blessing, 2013). Despite to the fact that several studies were conducted to explore the essentiality of IT to the activities of tertiary institutors (Collis, 2002 Soloway \& Pryor, 1996), nevertheless there is not much to write home about on the impact of IT capability in Nigerian tertiary institutions (Adeoye, et al. 2013). 


\subsection{LITERATURE REVIEW}

\section{Competitive Challenges in Nigerian Public Tertiary Institutions}

Nigerian public tertiary institutions are faced with myriad of competitive challenges. One of the pronounce challenge is proliferation of private universities. Or as simply put by Levy (1986) 'private challenges to public dominance in education'. The emergence of private tertiary institutions in Nigeria alongside with the opening of "corporate universities" or high talented education programmes are indeed reasons for public tertiary institution to discern that finally competition has emerged in the Nigerian higher education sphere (Oyediji, 2012). Great emphasis is now being given to the institutions on how to improve and gain advantages that are more competitive.

One of the competitive challenge facing the Nigerian public tertiary institutions is the outflow of Nigerian students abroad. According to Deji-Folutile (2014), the former Nigerian central governor Malam Sanusi Lamido Sanusi lamenting that there are about 71,000 Nigerian students in Ghana paying almost a billion US dollars annually. Furthermore, Exams Ethics International, a non- governmental organization had confirmed that the expenses of Nigerian students abroad is more than NGN1.5 trillion annually (Nigeria Spends, 2014). Incessant strikes in the institutions that lead to disruption of schools academic calendar and other performance problems are the reasons behind this outflow according to the NGO (Nigeria Spends, 2014).

IT is a transformational tool which, when used properly exploited, can accelerate the change to a learner- cantered environment (Achimugu, Oluwagbemi, Oluwaranti, 2010). The function of IT capabilities in enhancing the competitive advantage of public tertiary intuitions is well documented in the extant literature. Several IT studies affirmed that IT capabilities provide a foundation for attaining competitive advantage (e.g. Bhatt \& Grover, 2005; Santhanam \& Hartono, 2003; Ringim, 2013). Several literatures agree that IT capabilities are resources that can aid an effective collection and utilization of information (Bharadwaj, 2000). Floyd \& Woolbridge, (1990) argued that IT capabilities increase service reliability, decrease transaction errors and enhance consistency in performance. Further opinions are that capabilities can contribute in enhancing service quality through better-customized services, and facilitating knowledge links for identifying and sharing organizational technical competence (Quinn, Baily, Herbert \& Willet, 1994)

\section{The Concept of Information Technology Capability}

Ross, Beath \& Goodhue in 1996, promulgated the concept of IT capability. They defined IT capability as tertiary institutions ability to bring together, integrate and deploy IT based resources. Tippins and Sohi (2003) posited that IT capabilities are the level to which the institutions are well equipped with IT objects, IT knowledge as well as effective IT operations. An excellent level of IT public tertiary institutions facilitate the smooth execution of the organization's strategies develops solid and cost effective systems within the organization (Bhatt \& Grover, 2005). Clark (1997) concurred that IT competency combined with other IT elements directly leads to institution's ability to quickly develop and deploy more innovative techniques that will enhance their performance and subsequently enhanced institution's competitive advantage.

\section{Components of IT Capability}

Powell and Dent-Micallef (1997) confirmed that IT alone could not produce sustained competitive advantage, rather influence other intangibles human and business resources to gain sustained competitive advantage. Thus, looking at it from the resource-based view (RBV) perspective, IT-related advantages may result from tertiary institutions developing capabilities that enhance their teaching and administrative activities that other institutions would find difficult to copy. Tippins and Sohi (2003) proposed three components of IT capability. These components are IT knowledge, operation and objects.

\section{IT knowledge}

It is the extent of which tertiary institutions obtain a body of technical knowledge about machineries, infrastructures or objects such as a computer-based systems. This could b expressed as contextual based know how that the institutions possess through its experience in IT facilities.(Ringim, 2013). IT knowledge is categorized as a subset of the more general conceptional set of knowledge.

\section{IT operations}

This refers to the operations techniques, made up of activities that are carried out that facilitate the achievement a particular goal. Operations techniques are manifestation of technical knowledge and skills that are the outcome of results in technical operations or skills. In tertiary institution context, IT operations are the degree to which an institution utilizes IT resources within the organization for teaching and research purposes. These activities supported by skills that summarize the knowledge within the institution.

\section{IT objects}

IT objects are the 'enablers' and are largely responsible for the current increases in information and communication production and ploferation (Glazer, 1991). As a tool, technical objects refer to gadgets which assist in the 'obtaining, processing, storage, dissemination, and use' of information (Martin 1988). For this paper, IT is conceptualized as the objects represented by computer-based hardware, software, buildings and support personnel.

\section{Role of IT Capability in Attaining Competitive Advantage for Public Tertiary Institutions}

Literature indicate that integrating IT in educational institutions has generally leads to radical shift from the traditional method of doing things to more innovative ways that are more directed/ didactic approach to a more student - centered/constructivist approach (Lopez, 2003; 
Kirschner \& Woperies, 2003). Langlois (2001) posited that IT in tertiary institutions of learning led to various innovations that makes teaching less expensive, enables lessons to be delivered speedily, provide consistent message, make possible working from any location anytime, updating contents easily and quickly, increase learners' retention as well as management of large group of students. Bassey, Okodolo and Akpanumoh (2009) argued that IT increase the productivity of lecturers and help teachers to be more effective and innovative.

Information technology enables tertiary institutions to introduce important organizational changes in the areas of reengineering, decentralization, flexible work arrangements and outsourcing (Gera and Gu, 2004). Furthermore, Floyd \& Woolbridge, (1990) argued that adoption of IT capability in public tertiary institutions would increase service reliability, decrease transaction errors and enhance consistency in performance in the institutions. Further opinions are that capabilities can contribute in enhancing service quality through better-customized services, and facilitating knowledge links for identifying and sharing organizational technical competence (Quinn, Baily, Herbert \& Willet, 1994)

\subsection{CONCLUSION}

Information Technology (IT) has immensely contributed to the quality and quantity of teaching and learning globally. What left is for public tertiary institutions in Nigeria to grab this opportunity by utilizing their capabilities that should be rooted in information technology. This will play a vital role toward tackling the competitive challenges bedeviling the institutions presently. Exploiting the benefits offered by information technology will certainly assist the institutions to be more innovative. This will subsequently lead to improvement of performance and gaining competitive advantage. The surest way to this is for the institutions to invest more on IT components (object, operation and knowledge). More so, the institutions must be ready to accept changes by embracing the culture of innovation. Because IT capability grows and mature, only in institutions that are innovative as well as ready and willing to accept change.

\section{References}

Achimugu, P. Oluwagbemi, O., Oluwaranti, A. (2010). An Evaluation of the Impact of ICT Diffusion in Nigeria's Higher Educational Institutions. Journal of Information Technology Impact, 10(1), 25-34

Adeoye, Y. M., Oluwole, A. F., \& Blessing, L. A. (2013). Appraising the Role of Information Communication Technology (ICT) as a Change Agent for Higher Education in Nigeria. International Journal of Educational Administration and Policy Studies, 5(8), 177-183.

Aljazeera (2016) Misreporting Africa Retrieved fromhttp://www.aljazeera.com/programmes/upfront/ 15 August 2016.

Bassey, S., Okodolo, D. \& Akpanumoh, U. (2009). ICT in the Management of Education for Sustainable Development in Africa. African Research Review, 3(3), 414428

Bharadwaj, A. (2000). A Resource-Based perspective on Information Technology Capability and Firm Performance: An empirical Investigation. MIS Quarterly, 24, 169-196.

Bhatt, G. D., Grover, V., \& GROVER, V. (2005). Types of information technology capabilities and their role in competitive advantage: An empirical study. Journal of Management Information Systems, 22(2), 253-277.

Collis, B. (2002). Information technologies for education and training. In Adelsberger H, Collis B \& Pawlowski J (eds.) Handbook on technologies for information training. Berlin:Springer Verlag.

Deji-Folutile, O. (2014, December7). More students seek higher education abroad. The Punch. Retrieved from www.punchng.com/education/more-student.

Farid, D., Nejati, M.M.\& Mirta, K.H. (2008). Balance scorecard in an Iranian universities and higher education institutions: implementation guide in an Iranian context. Annals of University of Bucharest, Economic Administrative Series. 2, 31-45

Floyd, S. W., \& Wooldridge, B. (1990). Path Analysis of the Relationship between Competitive Strategy, Information Technology and Financial Performance. Journal of Management Information Systems, 7(1), 47-64.

Glazer R. (1991). Marketing in an Information-Intensive Environment: Strategic Implications of Knowledge as an Asset. Journal of Marketing, 55, 1-19.

Gera, S. \& Gu, W. (2004). The Effect of Organizational Innovation and Information and Communication Technology on Firm Performance. International Productivity Monitor, Nov. 9, 2004. Retrieved from http://www.csls.ca/ipm/9/gera_gu-e.pdf. 17th August, 2015.

Gusau, B. U. (2008). Educational Reforms In Nigeria: Successive Years Of Inconsistencies And Confusions. Paper Presented At Gusau Educational Development Association (GEDA) Interactive Session, January, 2008. Retrieved from: http://www.gamji.com/article6000/news7831.htm on 08 November, 2016.

Kazee, S. (2010). Expressive Qualities In Music Education: An Analysis Of The Extent To Which Expressive Qualities Are Valued By K-12 Public School Music Teachers, And The Impact Of Those Values On Educational Leadership Practices And Policy Initiatives. Retrieved from:http://scholarcommons.sc.edu/etd/974/ on 2/4/2016

Kirschner, P., \& Woperies, I.G.J.H. (2003). Mind tools for Teacher Communities: AEuropean Perspective (Electronic version). Technology, Pedagogy and Education, $12(1), 127-149$.

Langlois, C. (2001). Sharing Knowledge and Experience in Implementing ICTs inUniversities. Report of IAU/UNSCO information centre on Higher education, International Association of Universities. EAU/IAU/IAUPRound Table. Skagen

Lopez, V. (2003). An exploration of the use of Information Technologies in the College Classroom. College Quarterly, 6(1), 8-88.

Macharia, J., \& Nyakwende, E. (2009). Factors Affecting the Adoption and Diffusion of Internet in Higher Educational Institutions in Kenya. Journal of Language, Technology \& Entrepreneurship in Africa, 1(2), 6-23.

Martin, J.R. (1998). Evaluating Faculty Based on Student Opinions: Problems, Implications and Recommendations from Deming's Theory of Management Perspective. Issues in Accounting Education, 13 (4), 1079-1095.

Nigeria Spends (2014, December 5). Premium Times. Retrieved from: www.premiumtimesng/news/107056-nigeria-spends 30 July, 2016

Oyedijo, A. (2012). Antecedents and Performance Outcomes of Strategic Planning in Nigerian Public Universities. International Journal of Asian Social Science, 2(4), 448-461.

Powell, T. C. \& Dent-Micallef, A., (1997). Information Technology as Competitive Advantage: The role of Human, Business, and Technology Resources. Strategic Management Journal, 18(5), 375-405.

Quinn, J. B., Baily, M. N., Herbert, G. R., \& Willett, D. (1994). Information Technology: Increasing Productivity in Services: Executive commentary. The Academy of Management Executive, 8(3), 28.

Ringim, K. J., Osman, N. H., Hasnan, N., \& Razalli, M. R. (2013). Exploring the Implementation of Business Process Reengineering in Banks. Asian Social Science, $9(11), 243$.

Soloway, E., \& Pryor, A. (1996). The Next Generation in Human-computer Interaction. Communications of the ACM, 39(4), 16-19.

Santhanam, R., \& Hartono, E. (2003). Issues in Linking Information Technology Capabilityto Firm Performance. MIS Quarterly, 27(1), 125-153.

Tippins, M. J., \& Sohi, R. S. (2003). IT Competency and Firm Performance: Is Organizational Learning a Missing Link? Strategic Management Journal, $24,745-761$. 